\title{
The Right to Cross-Examination and Witness Protection in Ethiopia: Comparative Overview
}

Tadesse Melaku *

\section{Abstract}

Cross-examination particularly in the context of criminal trial is a human right recognized in international human rights law and the Ethiopian constitution. However, states are increasingly facing another pressing policy consideration protecting prosecution witnesses who could otherwise be subject to intimidation, and who could even risk their lives for providing evidence in the administration of criminal justice. Witness protection has become an important public interest that justifies the restriction of the right to cross-examination. Without such protection, witnesses could be uncooperative for fear of reprisal and, in view of this, many countries (including Ethiopia) have introduced measures restricting face-to-face examination through, among others, the suppression of witness identity. A review of foreign academic literature and foreign case law reveals that, when considering demands for anonymity, courts exercise maximum caution to ensure that the right to cross-examine witnesses is not unduly infringed. The writer argues that a recent constitutional ruling by the Council of Constitutional Inquiry in favor of withholding the identity of prosecution witnesses has failed to properly balance between the right to cross-examine against protecting witnesses. The ruling is likely to have a negative effect on fair trial and can adversely affect the fundamental rights of accused persons in Ethiopia

\section{Key terms}

Anti-Terrorism Proclamation · Council of Constitutional Inquiry · Right to cross-examination - Ethiopian Constitution · Fair trial $\cdot$ Protection of witnesses and whistleblowers

DOI http://dx.doi.org/10.4314/mlr.v12i2.3

This article is licensed under a Creative Commons Attribution-NonCommercialNoDerivs (CC BY-NC-ND)

\section{Introduction}

This article seeks to explore the tension between the right of accused persons to examine state witnesses face-to-face and the need for protectin the safety of

\footnotetext{
* Tadesse Melaku (LLB, LLM); Assistant Professor at Hawassa University, College of Law and Governance, School of Law. I thank the anonymous reviewers for their comments and suggestions. Email: <tadessehello@gmail.com>
} 
witnesses. In doing so, the study focuses on examining the validity of the recommendation by the Council of Constitutional Inquiry (hereinafter CCI) that upheld the withdrawal of witness identity in a criminal case. The ruling was made following a petition contesting the validity of the anti-terrorism and the witness protection proclamations by MehadiAley and others who were charged with terror-related crimes. The ruling has a direct impact on -if not complete deprivation of - the right of the accused to cross-examine. With a view to draw lessons from other jurisdictions and Ethiopia's tradition, the writer has reviewed the experience of other countries. The choice of foreign jurisdictions is, however, based on availability of source materials.

Cross-examination is key to a fair court trial process. It provides an opportunity to challenge the trustworthiness of a witness and expose lies and contradictions in the oral account by a witness. The demeanor of the witness, the manner of giving her testimony, her physical and emotional reaction to questions in cross-examination may hold the key to ascertaining the veracity of the testimony. The significance of confrontation for the defense is, therefore, very critical. In view of this, the Constitution of the Federal Democratic Republic of Ethiopia and the International Covenant on Civil and Political Rights (ICCPR) embody the right of the accused to cross-examine witnesses.

However, guaranteeing the well-being of those who give evidence essential to establish a criminal act is (and should be) an equally important public policy. If the witness refuses to come forward and give evidence for fear of revenge by the accused and his associates, that would have a chilling effect on the criminal justice system. Accordingly, many states, including Ethiopia, have enacted laws providing for the protection of witnesses. The Ethiopian proclamations on witness protection and terrorism authorize the suppression of information about witness identity and admissibility of hearsay and intelligence reports as evidence in court, thus, restricting the right to confront and examine one's accusers.

Cross-examination is said to be "basic to any civilized notion of a fair trial", "of paramount importance to the rights of the defense and the fairness of the trial" and "the greatest legal engine ever invented for the discovery of truth". ${ }^{2}$ Cross-examination is one aspect of the right to a fair and public trial guaranteed in international human rights $\mathrm{law}^{3}$ and under the Ethiopian constitution. ${ }^{4}$ Art

\footnotetext{
${ }^{1}$ Footnotes omitted. David Lusty (2002), “Anonymous Accusers: An Historical and Comparative Analysis of Secret Witnesses in Criminal Trial”, Sydney Law Review, vol. 24 <http://www.austlii.edu.au/au/journals/SydLawRw/2002/17.pdf > accessed 23 September 2017, pp. 361-362.

${ }^{2}$ Footnotes omitted. Ibid.

${ }^{3}$ Universal Declaration of Human Rights (1948), Art 10; International Covenant on Civil and Political Rights (ICCPR) (1966), Art 14(5).

${ }^{4}$ Constitution of Federal Democratic Republic of Ethiopia (1995), Art 20(4).
} 
14(5) of the ICCPR, which is considered as an integral part of the Ethiopian legal regime, guarantees the right of the accused "to examine, or have examined, the witnesses against him".

In Mattox v. United States, the US supreme court gave convincing reasons for face-to-face examination: to ensure that witnesses would testify under oath and understand the serious nature of the trial process; to allow the accused to cross-examine witnesses who testify against him; and to assess the credibility of a witness by observing that witness' behavior. ${ }^{6}$ The appearance of the witness in the courtroom enables the judge and the accused observe his/her reactions while being questioned and this may be crucial to assess the credibility and trustworthiness of the evidence. ${ }^{7}$

On the other hand, as various foreign case laws indicate, witness safety is a valid ground to restrict the confrontation rule without which obtaining testimonial evidence would be a daunting task. The lack of protection to the witness, her family or property could render the criminal justice system impotent. ${ }^{8}$ In light of this, governments are taking steps for increased witness protection, especially in the face of rising organized crime and terror. In Britain, for example, many witnesses experienced one of "the gravest" intimidations in relation to the conflict in Northern Ireland in the early 1970s. Thus, Lusty observes:

The main obstacle to dealing effectively with terrorist crime in the regular courts of justice is intimidation by terrorist organizations of those persons who would be able to give evidence for the prosecution if they dared... The fear of revenge upon 'informers' is omnipresent... It extends to all classes of society. It is not an idle or irrational fear. It is justified in fact by many wellauthenticated instances of intimidation, and not least by the example, familiar to all other potential witnesses, of a witness who was shot dead in his home in front of his infant child the day before he was due to give evidence on the prosecution of terrorists. ${ }^{10}$

\footnotetext{
${ }^{5}$ Id, Art 9(4).

${ }^{6}$ Witness protection during the prosecution and trial: Witness protection measures <https://www.alrc.gov.au/publications/right-confront-witnesses-and-test-evidence> accessed 12 September 2017

${ }^{7}$ Ibid.

${ }^{8}$ Harris quoted in Nicholas Fyfe and Heather McKay (2000) "Desperately Seeking Safety: Witnesses' Experiences of Intimidation, Protection and Relocation" in The British Journal of Criminology, vol. 40, no. 4. Oxford University Press. pp. 675-691 <http://www.jstor.org/stable/23638491> Accessed: 21-08-2017

${ }^{9}$ Lusty, supra note 1, p. 385.

${ }^{10}$ Ibid.
} 
The first section of this article provides a historical account of crossexamination and its restrictions focusing on its development in Europe and Ethiopia. The second section dwells on foreign laws and court decisions with a view to better understand the concept and the limitations necessitated by the need to protect evidence and the well-being of witnesses. The third and fourth sections respectively examine relevant Ethiopian laws the decision of from the Council of Constitutional Inquiry.

\section{Cross-Examination and Witness Anonymity in the Past}

In this section, we will examine the development and evolution of crossexamination and its corollary, anonymity, in European and Ethiopian traditions. Although anonymity existed in both Europe and Ethiopia, there are differences in the way it was enforced. In the former, suppression of witness' identity was practiced in exceptional circumstances. Ethiopia's tradition is characterized by an open and confrontational litigation between the accuser and the accused, testimonial statements were given in secret, at least with regard to afersata, as we will see later.

\subsection{European historical account}

The practice of face-to-face confrontation in a court trial goes back to ancient times as the following account reveals:

An early illustration of this right is provided in the biblical account of the trial of Paul (c $60 \mathrm{AD}$ ), who was accused of sedition as 'a ringleader of the sect of the Nazarenes'. Roman Governor of Judea, Festus, refused requests for the summary execution of Paul, declaring: 'It is not the manner of the Romans to deliver any man up to die before the accused has met his accusers face to face, and has been given a chance to defend himself against the charges'. ${ }^{11}$

However, the cross-examination faced a setback in the Middle Ages after the administration of justice was criticized for being too lenient towards the accused. Then, the Catholic Church and European states introduced stringent procedures in the name of protecting the public interest. ${ }^{12} \mathrm{~A}$ system of inquisitional investigation and prosecution was introduced as a result of which any person could be charged based on a vague and unfounded allegation. ${ }^{13}$ Governments legalized torture as a lawful technique of crime investigation.

The church, on its part, employed inquisition to investigate offenses involving heresy and, with respect to this particular offense, it too, used torture

\footnotetext{
${ }^{11}$ Id, p. 363.

12 Ibid.

${ }^{13}$ Ibid.
} 
and capital punishment. Restrictions on defense witnesses were strictly applied but those restrictions did not apply to state witnesses, hence, the double standard nature of the trial. As Lusty noted, "All statements adverse to the accused '[were] freely received, whether based on knowledge or prejudice, hearsay evidence, vague rumors, general impressions, or idle gossip". This approach was justified as proper in dealing with the then pressing issue of heresy in view of "the high risk of reprisals against those who testified against their neighbors"14 The English philosopher Bentham criticized the inquisition as a system whereby evidence was taken under a 'veil of secrecy' and the door was left 'wide open to mendacity, falsehood, and partiality",. 15

Even then, witness anonymity was considered as an exception that applied only when a demonstrated risk to a witness existed and the matter was to be determined on a case-by-case basis. ${ }^{16}$ Put another way, withholding of names and identities of witnesses was not a matter of principle but of exception. Ultimately, the inquisition was abolished in 1834 and the period of its application is described "as among the darkest blots on the record of mankind." 17 It is also viewed as an instrument of revenge for political and personal reasons that paved the way for "perjury and malicious testimony". 18

At the beginning of the $20^{\text {th }}$ century, face-to-face examination was considered as a valuable means to check the truthfulness of testimonies. In the end, the adversarial system emerged as a mechanism to counterbalance the weight of the testimony of the accuser and ensure the equality of arms in the legal battle. ${ }^{19}$

\subsection{Ethiopian Historical Account: Overview of Afersata and Leba Shay}

Ethiopia has a long history and over eighty ethno-linguistic communities. This section focuses on two traditional investigation schemes that were practiced in various parts of the country. Although customary law holds marginal place in the modern state law of Ethiopia, it is still the predominant mode of conflict resolution mechanism outside the state apparatus, including in criminal matters.

\footnotetext{
${ }^{14}$ Id. Footnotes omitted. p. 366.

${ }^{15}$ Witness protection during the prosecution, supra note 6.

${ }^{16}$ Footnotes omitted. Lusty, supra note 1, p. 368.

${ }^{17}$ Footnotes omitted. Ibid.

${ }^{18}$ Footnotes omitted. Id, p. 369.

${ }^{19}$ The Harvard Law Record, Confrontation: Getting It

Right<http://hlrecord.org/2015/09/confrontation-getting-it-right/> accessed 20 September 2017
} 
Staley Fisher noted that the multitude of ethnic communities had their own dispute settlement procedures operating parallel to the state structure. ${ }^{20}$

Although the FDRE Constitution confines the power of customary courts to decide personal and family matters and only with the consent of the disputing parties ${ }^{21}$ customary laws are indeed applied in various aspects of social conduct especially in the countryside. As Endalew Lijalem notes:

In many regions of Ethiopia, the customary norms are stronger, more relevant, and accessible than imposed and top-down legal norms. Moreover, experiences in different regions of Ethiopia show that people, even after passing through the procedures and penalties in the formal criminal court, tend to use the customary dispute resolution mechanisms for reconciliation and in order to control acts of revenge. ${ }^{22}$

Afersata and Leba Shay were the two most widely used traditional modes of crime investigation and prosecution. Afersata (Afan Oromo) is probably the most widely used mode of crime investigation and prosecution. It is also known as awuchachign in (the former provinces of) Shewa and Wollo; ewuse, in Gojam. ${ }^{23}$ The operation of Aftersata is initiated by the injured party and, in case of serious offences by local officials, then the village leader would call a meeting of community for the inquiry. At the gathering, every individual would, turn by turn, communicate to the elderly the name of the person whom he suspects of committing the crime. ${ }^{24}$

Fisher describes the procedure in detail. With regard to the technique of affersata and the incentive to name the offender, he states the following:

The technique used was to summon all inhabitants of the neighborhood where the crime was committed, and to sequester them until they named the criminal. Failure to attend the affersata was sanctioned by an "absence fine," and the assembly's failure to name the criminal resulted in communal liability to repair the damage caused by the offense. The wish to avoid this liability, together with the serious hardship caused by sequestration of the

${ }^{20}$ Stanley Z. Fisher (1971), "Traditional Criminal Procedure in Ethiopia" in The American Journal of Comparative Law, vol. (American Association for the Comparative Study of Law), pp. 716-724.

${ }^{21}$ Constitution of Ethiopia, supra note 4, Art 34(5).

${ }^{22}$ Endalew Lijalem (2014) Ethiopian Customary Dispute Resolution Mechanisms: Forms of Restorative Justice? <http://www.accord.org.za/ajcr-issues/\%EF\%BF\%BCethiopiancustomary-dispute-resolution-mechanisms/> accessed 20 September 2017

${ }^{23}$ Fisher, supra note 20, p. 716. Minor adjustments are made in the spelling of some words to make them consistent with the commonly used approach. For example "iwus" in the original is written as ewus.

${ }^{24}$ Aberra Jembere, An Introduction to the Legal History of Ethiopia: 1434-1974 (Shama Books, Addis Abeba, 2012), p. 239. 
whole community (it was reportedly decreed: "not a cow be milked nor a baby suckled" until the investigation was over), provided ample incentive to name the offender if that was possible. ${ }^{25}$

Affersata was a collective community endeavor to find out a crime suspect and establish his guilt. During this cumbersome process, participants could not go to their homes or attend their livestock and crops. The swearing in the name of God and Virgin Mary must have been a powerful psychological force to persuade the people to speak the truth. One should also note that Ethiopians have been, at least in the past, God-fearing people with deep reverence to spiritual life. ${ }^{26}$

Based on the reliability of the sources, testimonies were divided into three: (i) eye-witnesses, those who saw the commission of the crime firsthand; (ii) those who witnessed relevant facts and circumstances about the occurrence of a crime soon before or after its commission; and (iii) those who would testify based on hearsay. ${ }^{27}$ The latter were called wof (literally, bird). An appeal was possible against conviction passed based on the testimony of birds only. What is interesting is that the identity of witnesses was not known to the accused or the public; the elderly responsible to hear testimony kept their names confidential. As a result, the suspect had no opportunity to confront his accusers. ${ }^{28}$ That means the accused could not question the witnesses testifying against him/her. So, traditionally, Ethiopia allowed anonymous testimony.

Afersata became unpopular because of the concomitant incontinence it caused to people who had to endure the sequestration for days, sometimes for weeks, away from their family, cattle and farms. The villagers had to also shoulder the burden of feeding local officials during the event. This is likely to encourage the people to make false accusations or false confessions. ${ }^{29}$ Witness anonymity sometimes led to false accusations. Thus, Fisher observed that "some criminals and others reportedly took advantage of the anonymity of the 'birds' to accuse innocent persons, perhaps personal enemies, who could never learn the identity of their accusers." ${ }^{30}$ Nonetheless, in the absence of trained professional detectives and prosecutors, it is likely to have served as deterrence

\footnotetext{
${ }^{25}$ Footnotes omitted. Fisher, Traditional Criminal Procedure, supra note 20, p. 717.

${ }^{26}$ As Blaten-Geta Mahteme-Selassie WoldeMeskel pointed out, Ethiopians attached great value to the virtues of justice, religion, patriotism and respect for social status. BlatenGeta Mahteme-Selassie quoted in Aberra, An Introduction, supra note 24, footnote 506, p. 238.

${ }^{27}$ Fisher, supra note 20, p. 719.

${ }^{28}$ Aberra, supra note 24, p. 239.

${ }^{29}$ Fisher, supra note 20.

${ }^{30}$ Ibid.
} 
for potential offenders. Owing to the problems related with Aftersata, a law was enacted during the reign of Emperor Haile Selassie (the Afersata Proclamation enacted in 1933) to curb unintended consequences of the institution.

The leba shay institution was another crime investigation technique among the inhabitants of the highland areas (including present-day Eritrea) and among the Oromo. ${ }^{31}$ The method was particularly applied to apprehend thieves and the fruit of their crime. Leba shay operated as follows. A young boy, before the age of puberty, is made to drink a beverage made of an intoxicating herb. ${ }^{32}$ Then the intoxicated boy is tied with a strip of cloth on his waist and the chief thiefseeker follows him holding the other tip of the strip until the boy is said to have identified the criminal. Both Fisher and Aberra Jembere give similar accounts on functioning of the leba shay institution. The following excerpt is from the latter's book.

... In the house where he [the boy] collapsed he would again be made to drink the beverage so that he could identify the particular individual from among the inhabitants of the house. The boy would push aside anyone he meets entering the house of the suspected culprit. Any person on whom he laid his hand would be taken as a suspect and brought before a court of law. ${ }^{33}$

This practice was clearly irrational and superstitious. First, the boy's "sniffing out" of the accused was considered conclusive evidence to prove guilt. Second, the role of thief-seeker involved a conflict of interest in that the payment for his service came from the fine imposed on the convicted person, thus, the incentive to secure false accusation. ${ }^{34}$ Fisher has more on this, "There are numerous reports of such abuses, extending even to accusations that the thief-seeker acted in cahoots with thieves, corruptly agreeing to provide "protection" by seeing that innocent parties were always "tagged" by the boy." Having regard to this, the government of the day took some reform measures to minimize abuses such as setting of a ceiling on the amount of fee and punishing those who falsely accused innocent people. ${ }^{35}$

\section{Current Experience of Cross-Examination and Anonymity in Various Jurisdictions}

This section highlights the practice of some jurisdictions. It focuses on case law to see how foreign courts handle the conflict between witness protection measures and the face-to-face examination principle.

\footnotetext{
${ }^{31}$ Ibid.

${ }^{32}$ Ibid.

${ }^{33}$ Aberra, supra note 24, p. 238.

${ }^{34}$ Fisher, supra note 20.

${ }^{35}$ Footnotes omitted. Ibid.
} 
Witness protection is not in principle available in the US "even in situations where the defendant or her associates threaten the physical safety of the witness." 36 The Constitution's confrontation clause does not have any limitations. ${ }^{37}$ The US Constitution guarantees "the right to be confronted with witnesses against him." 38 Despite the absence of constitutionally defined restrictions on the right, judges have qualified it particularly in the aftermath of the women's rights movement that led to the enactment of rape shielding laws. These laws give immunity for rape victims from being questioned about their prior sexual life during cross-examination and courts are consistent in upholding the validity of those laws. ${ }^{39}$ Other protection devices include pre-trial detention of the accused and other safety programs. In recent times, federal and state judges have increasingly granted requests for anonymity. ${ }^{40}$

Anonymous informants are also allowed in so far as there is other evidence sufficient to prove the charge. For example, in Romero v. State, a US court held that, confrontation can be restricted only to uphold "an important public interest and when the reliability of the testimony is otherwise assured". 41 Here the important public interest is the safety of a witness. ${ }^{42}$

In United States v. Jesus-Casteneda, the court of appeal came up with certain criteria to determine admissibility of evidence given in disguise with a witness wearing artificial mustache and wig. The court reasoned:

Applying that rule here, the CI's [confidential informant] disguise in the form of a wig and mustache was necessary to further an important state

${ }^{36}$ Nora Demleitner (1998) Witness Protection in Criminal Cases: Anonymity, Disguise or Other Options, 46 Am. J. Comp. L. Supp. p. 641.

<http://scholarlycommons.law.wlu.edu/cgi/viewcontent.cgi?article=1271\&context=wlufac > accessed 23 Sept 2017

${ }^{37}$ USA and Ethiopia share the notion of constitutional supremacy which places their constitutions at the top of the legal hierarchy within the respective jurisdictions.

${ }^{38}$ The Sixth Amendment to the US Constitution.

${ }^{39}$ Demleitner, Witness Protection in Criminal Cases, supra note 36, pp. 641-645.

${ }^{40}$ Ibid.

${ }^{41}$ Emphasis added. Romero v. State (2013 discussed in "Open Issue: The Constitutionality of Permitting Testimony by A Disguised Witness", Federal Evidence Review) $<\mathrm{http} / / /$ federalevidence.com/blog/2013/february/disguised-witness-and-confrontationclause > accessed 21 September 2017

${ }^{42}$ Another exception is the case of child witnesses in view of their low level personal emotion. This was the holding of the supreme court in the case of Maryland v. Craig whereby the court decided to allow an alleged child victim "to testify by one-way closed circuit television" as, the court added, face-to-face confrontation may cause "serious emotional distress for the child". Right to Confront Witness (Legal Information Institute) <https://www.law.cornell.edu/wex/right_to_confront_witness > accessed 20 September 2017 
interest, namely a witness's safety. The government offered reasons for protecting the Cl's identity, given his continuing involvement in Sinaloa Cartel drug investigations as an undercover agent. Second, the reliability of the Cl's testimony was otherwise assured, because (1) he was physically present in the courtroom, (2) he testified under oath, thus impressing him with the seriousness of the matter and the possibility of penalty for perjury, (3) he was subject to cross-examination while Appellant could see him, (4) despite his disguise, the jury was able to hear his voice, see his entire face including his eyes and facial reactions to questions, and observe his body language. These are all key elements of one's demeanor that shed light on credibility. Thus, we hold that in this case, the disguise in the form of a wig and mustache did not violate the Confrontation Clause. ${ }^{43}$

In Smith v Illinois, ${ }^{44}$ a key prosecution witness testified under a false name. The witness was cross-examined on his testimony, but the trial judge prevented the defense from ascertaining his true name and address. The Supreme Court reversed the conviction by a majority stating:

In the present case, there was not, to be sure, a complete denial of all right of cross-examination. But the petitioner was denied the right to ask the principal prosecution witness either his name or where he lived... Yet when the credibility of a witness is in issue, the very starting point in "exposing falsehood and bringing out the truth" through cross-examination must necessarily be to ask the witness who he is and where he lives. The witness' name and address open countless avenues of in-court examination and outof-court investigation. To forbid this most rudimentary inquiry at the threshold is to effectively emasculate the right of cross-examination itself.

In $R v$ Taylor (UK) the court held that '[t]he right of the accused to see and know the identity of his accusers should only be denied in rare and exceptional circumstances. Whether the exception was made out was pre-eminently a matter for the discretion of the court". ${ }^{45}$ The court proceeded to set out the following standards in exercising the discretion:

1. There must be real grounds for fear of the consequences if the evidence were given and the identity of the witness was revealed....

2. The evidence must be sufficiently relevant and important to make it unfair to make the Crown proceed without it. ...

\footnotetext{
${ }^{43}$ United States v. Jesus-Casteneda (summary of the court's ruling) <http://federalevidence.com/pdf/2013/01Jan/US.v.Jesus-Casteneda.pdf > accessed 7 October 2017

${ }^{44}$ Lusty, supra note 1, p. 379.

${ }^{45} \mathrm{R}$ v Taylor, cited in Id, p. 393.
} 
3. The Crown must satisfy the court that the creditworthiness of the witness had been fully investigated and disclosed.

4. The court must be satisfied that there would be no undue prejudice to the accused ...

5. The court could balance the need for protection of the witness, including the extent of that protection, against unfairness or the appearance of unfairness. ${ }^{46}$

The European Court of Human Rights (ECtHR) stated that before a suspect is convicted, he/she must, in principle, have an opportunity to challenge the truthfulness and reliability of a testimony. ${ }^{47}$ The Court has, however, acknowledged exceptions to the right of the defendant "to be confronted with the witnesses against him" ${ }^{48}$ In Ludi $v$ Switzerland ${ }^{49}$ the same court overturned a criminal verdict "based on a written statement by an undercover agent and a written transcription of telephone conversations with the defendant". In this case, the accused had no opportunity to examine the state witness before or during the trial.

But in Asch v Austria ${ }^{50}$, the ECtHR did not find violation of the Convention even though the court of first instance relied on evidence by a police officer and a physician who had examined the victim-witness, although the victim later refused to testify at the trial. Thus, the conviction handed down based on the pre-trial record was affirmed. Here the evidence from the investigating police officer and the physician corroborated the witness's pre-trial statement. In other words, the domestic court did not depend solely on the testimony of the victimwitness.

On the contrary, in P.S. $v$ Germany, ${ }^{51}$ the domestic court, in finding the accused guilty, relied entirely on a statement of an eight-year-old girl who was allegedly sexually abused by her music teacher. The German court did not require the victim to testify at the trial so as to protect her personal development. The ECtHR considered the conviction as a breach of the suspect's right under the Convention since pre-trial statement of the witness became the sole and

\footnotetext{
${ }^{46}$ Ibid.

${ }^{47}$ Lorena Bachmaier Winter, "Transnational Criminal Proceedings, Witness Evidence and Confrontation: Lessons from the ECtHR's Case Law", Utrecht Law Review <https://www.utrechtlawreview.org/articles/abstract/10.18352/ulr.246/> accessed 23 September 2017

${ }^{48}$ European Convention on Human Rights (1950), Art 6(3)(d).

${ }^{49}$ Winter, supra note 47.

${ }^{50}$ Ibid.

${ }^{51}$ Ibid.
} 
decisive evidence in finding the accused guilty of the crime he was charged with.

South Africa is said to have "experienced one of the worst intimidations anywhere in the world" 52 during the apartheid era and the threat was directed against former ANC members who appeared in court to testify against their former freedom fighter colleagues. In 1985, the high court decided the case of $S$ $v$ Leepile in which the state demanded the withholding of the identity of its witnesses. Rejecting the request, the judge noted:

(a) No investigation could be conducted by the accused's legal representatives into the witness' background to ascertain whether he has a general reputation for untruthfulness, whether he has made previous inconsistent statements nor to investigate other matters which might be relevant to his credibility in general. (b) It would make it more difficult to make inquiries to establish that the witness was not at places on the occasions mentioned by him. (c) It would further heighten the witness' sense of impregnability and increase the temptation to falsify or exaggerate. ${ }^{53}$

It is also worthy to note that intimidation often results from underlying social grievances. As South Africa's experience shows, prosecution witnesses under apartheid were frequently targeted because their participation as witnesses against their former colleagues was considered as betrayal of a just cause, collaboration with an unjust regime. Thus, it comes as no surprise that the ANC "openly called for the assassination of known informers and detailed brutal killings of former members who served as state witnesses, describing them as 'just reprisals'. ${ }^{54} \mathrm{We}$ also find a similar account that took place in Europe in the middle ages. Individuals who testified before the inquisition, considered earlier, became targets of violence because their action was deemed to have exposed fellow citizens to unjustified punishment. ${ }^{55}$ In short, the motive for revenge is much deeper than just hate to individual witnesses.

In other jurisdictions, witnesses have encountered serious, and in some cases, life-threatening intimidation. ${ }^{56}$ The degree of risk also varies greatly.

[The defense] will often attempt 'to make witnesses appear so inconsistent, forgetful, muddled, spiteful, or greedy that their word cannot be safely believed. ... [I]t is of little surprise... witnesses frequently leave the witness

\footnotetext{
${ }^{52}$ Lusty, supra note 1, p. 401.

${ }^{53}$ Footnotes omitted. Id, p. 402.

${ }_{55}^{54}$ Id, p. 401.

${ }^{55}$ Id, p. 368.

${ }^{56}$ Karen Kramer, Witness Protection as a Key Tool in Addressing Serious and Organized Crime <http://www.unafei.or.jp/english/pdf/PDF_GG4_Seminar/Fourth_GGSeminar_P3> p. 5 . Accessed 5 October 2017
} 
box 'angrily and in tears'. In addition, simply being in the witness box makes individuals vulnerable to verbal abuse and threats shouted from the public gallery or being stared at by the accused. Moreover, when trials end or adjourn, suspects, victims, and witnesses may all move out of the room into the public waiting areas of the court building where further intimidation occurs.

Aside from organized and other serious offenses, most witnesses do not face serious risk to their lives. Rather they tend to experience "verbal threats, intimidation, harassment, assault, property damage or simply fear of reprisal as a result of their cooperation with" 57 law enforcement personnel.

Progress has been made in recent times, mainly due to "the increased impact of organized criminal and terrorist groups". 58 On the global level, the UN General Assembly adopted a resolution which calls for the implementation of "measures to minimize inconvenience to victims, protect their privacy, when necessary, and ensure their safety, as well as that of their family and witnesses on their behalf, from intimidation and retaliation". ${ }^{59}$ As part of this global movement, Ethiopia has enacted legislation governing the protection of witnesses and whistleblowers discussed below.

\section{Ethiopia's Legal Framework}

\subsection{Right to Cross-Examination}

Under Art 20(4) of the Ethiopian Constitution, accused persons are entitled to have "full access to any evidence presented against them, to examine witnesses testifying against them". ${ }^{60}$ The 1961 Criminal Procedure Code recognizes the same right in Art 136. However, the Code differs from the Constitution with respect to the scope of the right. The Code limits its scope "to show to the court what is erroneous, doubtful or untrue in the answers given in examination-inchief" ${ }^{\prime 61}$ (emphasis mine). In this regard, the Constitution is progressive in the sense that it stipulates a broader right to accused persons to have "full access to any evidence presented against them, to examine witnesses testifying against

\footnotetext{
57 Ibid.

${ }^{58}$ Ibid, p. 11.

59 Declaration of Basic Principles of Justice for Victims of Crime and Abuse of Power (1985) (General Assembly resolution 40/34, annex), Parag. 6 of the Declaration(d).

${ }^{60}$ The 1931 and 1987 constitutions of Ethiopia did not specifically guarantee the right to cross-examination. Art 52 of the 1955 constitution, probably modeled after the Sixth Amendment to the US constitution, recognized the right of the accused "to be confronted with the witnesses against him".

${ }^{61}$ Criminal Procedure Code of Ethiopia (1961), Art 137(3).
} 
them" (emphasis mine). Put another way, "full access to any evidence" seems to imply that the personality and credibility of the witness are also the subject of examination by the other side; the testifier and the testimony are inseparable. Furthermore, the reading of the foreign academic literature and foreign case law clearly reveals that the right of confrontation extends far beyond the testimony given in the courtroom). Confrontation offers the accused with the opportunity to discredit the witness's trustworthiness as well.

A literal interpretation of Article 20(4) of the Constitution does not warrant any restriction on the right. ${ }^{62}$ However, as discussed before, an absolute crossexamination right is problematic. In the words of Eva Brems, "The priority of human rights that holds in principle does not hold in every concrete case.",63 Similarly, Daniel Betancourt observed that:

To resolve whether anonymity should be allowed or not, first, we have to consider that law is not an exact science. In law, there are general rules, but always there are some exceptions. It is not possible to have only one formula and give the same interpretation to every case. For that reason, justice needs to adapt and the courts should interpret the legal bodies according to the specific case. Every rule has exceptions[sic], and without doubt anonymity as well. $^{64}$

In the Ethiopian legal system, the Anti-Terrorism Proclamation (ATP) and the Proclamation on Protection of Witnesses and Whistleblowers (PWW) contain limitations on the exercise of cross-examination. This move by the federal legislature appears justified on pragmatic considerations - the interest of the public and of the individual witness. However, these laws contain substantial modification on the constitutional right.

There are also other legal rules that conflict with Art 20(4) of Constitution. First, Articles 144 and 145 of the Criminal Procedure Code (CPC) make out-ofcourt testimony and expert opinion admissible as evidence in court. ${ }^{65}$ Art 144(1) reads, "The deposition of a witness taken at a preliminary inquiry may be read

\footnotetext{
${ }^{62}$ Whether such limits call for a constitutional amendment is, however, another matter. As the experience of some states of United States reveals, such limits have to be applied only after a constitutional change. pp. 643-644.

${ }^{63}$ Eva Brems (2005) "Conflicting Human Rights: An Exploration in the Context of the Right to a Fair Trial in the European Convention for the Protection of Human Rights and Fundamental Freedoms", Human Rights Quarterly. The Johns Hopkins University Press, vol. 27, no. 1, pp. 294-326. <http://www.jstor.org/stable/20069786> accessed 4 October 2017

${ }^{64}$ Daniel Betancourt (2010)Anonymity as Protective Measure for Victims and Witnesses $v$. The Rights of the Accused. Tilburg University, master's thesis. p. 47.< http://arno.uvt.nl/show.cgi?fid=120647> accessed 23 September 2017, p. 48.

${ }^{65}$ The constitutionality of these provisions has not been challenged in Ethiopia to date.
} 
and put in evidence... where the witness is dead or insane, cannot be found, is so ill as not to be able to attend the trial or is absent" from the country. Although US courts permit the testimony of an absent witness, ${ }^{66}$ there is a clear divergence between the US and the Ethiopian laws. In Ethiopia, the accused cannot cross-examine the witness at the preliminary inquiry; he is a passive observer while the prosecutor and the judge are the main actors. ${ }^{67}$

Second, the same argument can be made against Art 145 which reads, "The deposition of an expert taken at a preliminary inquiry may be read and put in evidence... although he is not called as a witness." 68 These provisions (i.e. Articles 144 and 145 of the Criminal Procedure Code) deny the suspect the chance to put questions to the public prosecutor's witnesses. They also fail to satisfy the requirement and purpose of oath in court which witnesses must invariably undertake before testifying. The administration of oath sends a message to the witness about the consequences of his word in a court of law and the sanction for perjury. ${ }^{69}$ So, Arts 144 and 145 of the CPC override the confrontation and oath requirements which are key reliability-ensuring mechanisms.

Third, as per Article 137 of the CPC, testimony based on one's "direct or indirect knowledge" is permissible as evidence in court. Again, this defeats the rationale for the confrontation right although foreign courts consider hearsay only under strict conditions. ${ }^{70}$ Hearsay evidence is given by a person who has no firsthand knowledge of the alleged act and is rather based on what one has heard others say. Such evidence is problematic as the witness is incapable of properly answering cross-examination questions.

The constitutionality of the hearsay rule has never been tested in Ethiopia to date; now, it is also incorporated in the Anti-terrorism Proclamation of 2009. In regard to the position of foreign judges, in the US, it has been ruled that hearsay restricts or violates the confrontation rule ${ }^{71}$ but it can be lawful if two conditions are present: when the witness is unavailable and, during previous court proceedings such as a preliminary inquiry, he/she had testified against the same defendant and was subject to cross-examination by that defendant. ${ }^{72}$ Thus, there

\footnotetext{
${ }^{66}$ See Barber v. Page, in Right to Confront Witness, supra note 42.

${ }^{67}$ Criminal Procedure Code, supra note 63, Art 80. Arts 80 and the following set forth the procedure for a preliminary inquiry.

${ }^{68}$ Id, Art 144(2).

${ }^{69}$ Id. In Art 136(2), the Criminal Procedure requires the administration of oath or affirmation before taking witness testimony.

${ }^{70}$ See, Barber v. Page, cited in Right to Confront Witness, supra note 42.

${ }^{71}$ Delaney v. United States, ibid.

${ }^{72}$ Barber v. Page, ibid.
} 
are legal rules in Ethiopia that evoke concerns regarding their consistency with the constitutional and human right to confrontation.

\subsection{Protection of witnesses and whistleblowers}

Testimony is perhaps the most widely used prosecution evidence and, without it, the criminal justice system would be ineffective, particularly regarding serious crimes. Without witness protection, the government's ability to prosecute and ultimately safeguard the public from crime would significantly diminish. Those who witnessed the commission of a crime would be discouraged from reporting and testifying for fear of reprisal.

The position of the witness raises both a legal and moral question. This can relate to a person who is trapped by the duty to testify, but not as a matter of personal choice in the case of serious crimes. Failing to do so amounts to "refusal to aid justice" $" 73$ and is punishable criminally.

While the right of the accused is unambiguously stated in the FDRE Constitution and ICCPR, no parallel safeguard exists for the witness. The right of the accused is given due attention in international and national laws. On the contrary, little attention is paid to the well-being of the witness who could be subject to harassment even at the risk of her life for cooperating with the prosecution. In terms of the law, the witness has been 'the forgotten soul of the criminal justice system'.

Lawmakers have been dragging their feet to respond to this pressing social problem. Of course, there are some legal provisions here and there on the subject but they are far from sufficient. To start with the FDRE Constitution, Art 20(1) refers to in camera proceedings with the view to ensure the privacy of parties, public moral and national security. Here the word parties, if interpreted literally, does not cover the witness. Thus, the personal safety of the witness has no constitutional basis for protection in Ethiopia. ${ }^{74}$

Other piecemeal rules include a provision in the Criminal Procedure Code that requires judges to deny bail if the suspect "is likely to interfere with

${ }^{73}$ Accordingly, Art 448(1) of the Criminal Code states:

"Any person who had been lawfully summoned to appear in judicial or quasi-judicial proceedings as an accused person, witness, expert, interpreter, assessor or juror; or ordered. to produce or send an accused person or evidence: (a) fails or refuses to appear without sufficient cause; or (b) fails to produce or send the accused person or evidence; or (c) having appeared, refuses, contrary to law, to answer questions or to obey orders, is punishable..."

${ }^{74}$ This is also the case in other systems such as the US; but courts elsewhere have read into some overarching interests (such as public policy and the necessities of the case) to limit face-to-face examination. Anonymous Accusers, n. 1, p. 377. 
witnesses or tamper with the evidence". ${ }^{75}$ Once again, the concern here is not the witness's security rather the preservation and integrity of his/her testimonial evidence. If the safety of the witness is protected as a result of the denial of bail, it is incidental. If there is any specific rule on the subject, it is only Article 444 of the Criminal Code which makes it a crime to assault, suppresses or harm "any person who gives information or evidence to justice authorities or is a witness in criminal cases". 76

The only law that provides a comprehensive coverage on witness safety measures and programs in this regard is the Protection of Witnesses and Whistleblowers of Criminal Offences Proclamation (PWW), i.e. Proclamation No. 699/2010. It has been enacted "to protect witnesses and whistleblowers of a criminal offense from direct or indirect danger and attack they may face as a consequence thereof and thereby to ensure their safety" ${ }^{77}$ This legislation applies to all crimes punishable with rigorous imprisonment for ten years or more (regardless of the minimum prison term threshold) or with capital punishment. ${ }^{78}$ The Proclamation puts preconditions before anonymity is granted. The conditions are, first, the offence must be such that it cannot be proved by a means other than the testimony of the witness or information from the whistleblower requiring protection and, second, there is reason to believe that a threat of serious danger exists to the life, physical security, freedom or property of the witness or his family.

Art 4(1) of the Proclamation provides details regarding the measures and programs applicable, severally or jointly, including the following: physical protection of person, residence and property of the witness; relocation at the expense of the state, change of identity, provision of self-defense weapon, immunity from prosecution for an offence for which he provides information, free medical service in public health institutions, counseling and opportunity for employment and education, covering cost of living in case of loss of capacity to work as a result of reprisal. Most of these programs may not affect the right of the defense to fair trial. As pointed out by Kramer, the purpose of protection "should never provide a motivation to testify but merely remove or counter the witness' view that he or she is in danger if he/she cooperates." 79 Indeed, witness protection should not create an incentive to testify because that would lead to a potential conflict of interests.

\footnotetext{
${ }^{75}$ Criminal Procedure Code, supra note 61, Art 67(c).

${ }^{76}$ Criminal Code of Ethiopia (2005), Art 444.

${ }^{77}$ Protection of Witnesses and Whistleblowers of Criminal Offences, Proclamation No.699/2010, Paragraph 3 of the Preamble.

${ }^{78} \mathrm{Id}$, Art 3(1).

${ }^{79}$ Kramer, supra note 56, p. 5.
} 
There are other provisions of the Proclamation that restrict or deny fair trial. The list of such legal rules affecting the accused' right includes changing identity of witness, the prohibition against the accused to contact the witness, taking testimony in camera and behind screen and providing evidence via electronic devices. ${ }^{80}$ In the face of such measures, it would be difficult, or even impossible, to expose contradictions, lies and prejudices thereby significantly reducing the chances of the defense to refute the charges against him. What if the witness is a false witness? What if the witness has some motive to falsely incriminate the suspect? How can the defense challenge the untrustworthiness of a witness by exposing, for example, his prior criminal record for perjury, misrepresentation or forgery? Should someone spend the rest of her life behind bar or lose her life because of false accusations? There is thus the need for safeguards against such risks, and cross-examination contributes toward fair trial thereby serving as one of the prevention schemes against of unwarranted convictions.

As the American Supreme Court once stated, confrontation is meant to prevent conviction "based on the charges of unseen and unknown -and hence unchallengeable individuals." ${ }^{\text {"11 }}$ The way the witness reacts to questions has evidentiary value; it is also part of the broader notion of fair trial. The demeanor of the witness, the manner of her testimony, the behavior she manifests while in the witness box, whether the witness is cooperative, evasive or nervous when answering questions, the character and personal impression she creates, her physical and emotional reaction can be indicative of the veracity of the oral evidence.

In addition to the Witness Protection Proclamation, we should add the Antiterrorism law which authorizes the removal of witness information from court records (including the publication and dissemination of such information) ${ }^{82}$ and the admissibility of intelligence report involving terror (even if such report does not mention the source or method of information gathering ${ }^{83}$ and hearsay evidence, ${ }^{84}$ digital or electronic evidence, ${ }^{85}$ evidence gathered through surveillance, information obtained through interception by foreign law enforcement bodies, ${ }^{86}$ a written confession and voice and video recording. ${ }^{87}$ The

\footnotetext{
${ }^{80}$ Protection of Witnesses and Whistleblowers, supra note 77, Art 4.

${ }^{81}$ Lee $v$ Illinois.

${ }^{82}$ Anti-Terrorism Proclamation No. 652/2009, Art 32(1)(b).

${ }^{83}$ Id, Art 23(1).

${ }^{84} \mathrm{Id}, \operatorname{Art} 23(2)$.

${ }^{85} \mathrm{Id}, \operatorname{Art} 23(3)$.

${ }^{86}$ Id, Art 23(4).

${ }^{87}$ Id, Art 23(5).
} 
law does not provide guidance on how to weigh the probative value of these evidences and whether they are sufficient to make a case against the suspect.

As for intelligence report, the high court of New Zealand rejected a request by the prosecutor to withhold names of undercover agents saying that the officers were of the highest integrity and, if their identity were to be revealed, they would not testify. The judge reasoned that:

I cannot agree with the submission. The real risk of prejudice to the defense and of conviction of the innocent would remain. A private assessment by the prosecution of the credibility of a police officer is no substitute in the interests of justice for a proper check of his background by the accused whose liberty is at stake and who stands condemned on the undercover officer's evidence if his credibility is unchallenged... Unless and until the defense ascertains the officer's name his background cannot be adequately checked in order to see whether there is justification for attacking his credibility. ${ }^{88}$

Both Proclamation 652/2009 and Proclamation 699/2010 are silent as to whether hearsay and intelligence reports are to be used as corroborative or conclusive evidence. In the case of US case law, the non-disclosure of part or all information about a witness is permitted but it has to be corroborated by other evidence. $^{89}$ For both American courts and ECtHR, witness anonymity is tolerated only in exceptional circumstances and, when allowed, the testimony is insufficient for conviction. Only time will tell how Ethiopian judges will interpret the law but parliament has failed to stress the place of crossexamination, as a fundamental right, in deciding demands for anonymous testimony.

The two proclamations vary concerning who decides on the issue of witness protection measures. Art Anti-Terrorism Proclamation allows witness protection "where the court, on its own motion or on an application made by the public prosecutor or by the witness, is satisfied that the life of such witness is in danger..." Accordingly, the power to allow or disallow an application rests with the court but Proclamation 699/2010 confers this power on the Ministry of Justice (currently the Federal Attorney General) and the Federal Ethics and Anti-corruption Commission the decision of which is not appealable. ${ }^{91}$ It

\footnotetext{
${ }^{88} R v$ Hughes discussed in Lusty, supra note 1, p. 399.

${ }^{89}$ Kramer, Witness Protection as a Key Tool, supra note 56, p. 6.

${ }^{90}$ Anti-Terrorism Proclamation, supra note84, Art 32.

${ }^{91}$ Witness Protection Act, 2015 [of India], Art 3(3); In South Africa the director, an appointee of the justice minister, is in charge to decide witness protection applications. Witness Protection Act 112 of 1998, Art 10(3)(a)(b)(c).
} 
follows that Proclamation 699/2010 has impliedly repealed the power of courts under Proclamation 652/2009.

This line of interpretation is further strengthened by the explicit reference to the Federal High Court which is empowered to approve protection agreements made by the Federal Attorney General with child witnesses. As far as adults are concerned, the responsibility is entrusted to the Ministry of Justice (currently the Federal Attorney General) and Ethics and Anti-corruption Commission. ${ }^{92}$ This shows usurpation of judicial power by the legislature in favor of the executive.

In contrast to the Ethiopian law, a US judge remarked that "the State or the witness should at the very least come forward with some showing of why the witness must be excused from answering the question. The trial judge can then ascertain the interest of the defendant in the answer and exercise an informed discretion in making his ruling." ${ }^{, 93}$ It is a matter of conventional wisdom that judges, if allowed to operate independently, become the custodian of human rights. The transfer of court power to the executive should be, therefore, a matter of grave concern.

\section{CCI's Decision in the Case of MehadiAley and others}

The case of MehadiAley and others involves a constitutional complaint by three persons accused of committing terror offences. ${ }^{94}$ During the hearing, they objected to the withholding of names and addresses of witnesses based on Art 32 of Proclamation 652/2009 which bestows power upon judges to allow anonymous applications. The defense argued that the failure to disclose witness identity by the prosecutor violated Art 20(4) of the Constitution. The defense also mentioned the absence of limit to the confrontation provision under the Constitution and demanded the advance disclosure of state witnesses so that they could prepare for the trial. They argued that their prior knowledge of the witnesses was crucial for the preparation of the defense and, ultimately, the fairness of the trial and the search for the truth. Consequently, the court referred the issue to the CCI for a constitutional ruling on the validity of Art 32(b) and Art 4 (1)(h)(j) of Proclamations 652/2009 and 699/2010, respectively.

After considering the petition, the CCI reasoned that:

"what can be understood from this provision [i.e. Art 20(4)] is that it affirms the right of accused persons to cross-examination but the defense has no right for the disclosure of names and addresses of witnesses. Nor does the

\footnotetext{
${ }^{92}$ Protection of Witnesses and Whistleblowers, supra note 77, Art 9(1)(2).

${ }^{93}$ Emphasis added. White J quoted in Lusty, Anonymous Accusers, supra note 1,p. 380.

${ }^{94}$ Mehadi Aley and others, File No. 2356/2009 (Council of Constitutional Inquiry, Hamle 29, 2009 E.C.)
} 
Constitution impose the duty on the prosecution to disclose such information. This is categorically expressed in the Constitution..."

The Council, in an apparent attempt to establish the intent of the framers of the Constitution, noted that "the reason for not including a requirement for disclosure in the Constitution is that it would pose danger to the safety of witnesses rather than ensuring the fairness of the trial." This conclusion is rather unwarranted and expansive in view of the fact that constitutions do not deal with such detailed matters. In the end, the CCI did not find inconsistency between the Constitution and the proclamations. ${ }^{95}$ Consequently, it ruled the proclamations were constitutionally valid.

Contrary to this, Lusty, while commenting on the US case law, noted that "the right of an accused to know the true identity of his or her accusers lies at the heart of the right of confrontation." 96 Again, in Barnard v Williams, a New Zealand judge held, "[t]he name could well lead to a line of inquiry that will throw doubt on or even destroy the value of testimony... to suppress identity is to change the character of the proceedings and ignore what I believe is a basic principle" 97 in a court trial. Examples of judicial decisions from other jurisdictions are not of course directly applicable to our legal system. Yet, we can make reference to a principle (that is also recognized under our Constitution) which is in tandem with such rulings upheld by courts of other countries.

The Council of Constitutional Inquiry should have clearly spelled out the absence of any constitutional limit to face-to-face examination. It would make sense if it tried to justify the contested laws based on pragmatic considerations using teleological reasoning. The Council rather offered a remote and unwarranted opinion to conclude that the Constitution anticipated the withholding of witness identity. Furthermore, the CCI has failed to properly articulate the importance of the fundamental human right to cross-examination, and the reasoning fails to appreciate the significance of fundamental rights.

\footnotetext{
95 The same conclusion was reached by the House of Federation in the case of Merera Gudina who also challenged the constitutionality of withholding names of prosecution

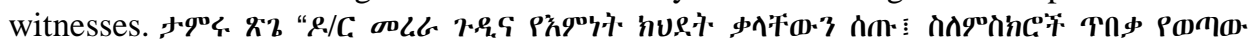

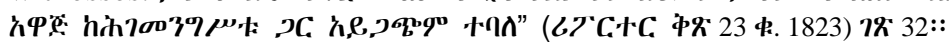

${ }^{96}$ Lusty, supra note 1, p. 380.

${ }^{97}$ Id, p. 397.
} 


\section{Conclusion}

The right of cross-examination is key feature of fair trial. From the perspective of the accused, it is an opportunity to challenge the credibility of witnesses testifying against him/her. Apart from face-face encounter in the courtroom, a meaningful cross-examination depends on before-trial knowledge of the witness' personal background whether, for example, he had prior conviction for perjury or misrepresentation. Prior knowledge creates avenues to discredit the testimony.

Thus, it comes as no surprise that cross-examination is recognized both in the domestic law of Ethiopia and international human rights law. On the other hand, witnesses may face harassment and life-threatening situations if their identity is disclosed to the defense. This has necessitated the protection of their safety without which the effectiveness of the criminal justice system would be in jeopardy for fear of reprisal.

The federal legislature has passed laws that embody witness protection measures and programs including concealment or change of witness identity. While the need to have witness protection laws is understandable and long overdue, care must be taken during application so as not to stretch them to the extent of jeopardizing the success of the defense and the fairness of the trial. The withholding of witness information can significantly diminish the ability of the accused to show the unreliability of the testimony of a state witness.

In Mehadi Aley and others, the CCI has not properly scrutinized the existence of specific factual and legal grounds justifying the suppression of identity of state witnesses. The decision was also reached without balancing the constitutionally guaranteed human right of the defense to cross-examination. Moreover, the CCI has indeed failed to give sufficient reasoning to support the holding. 